\title{
First record of the smoky bat Furipterus horrens (F. Cuvier, 1828) (Mammalia: Chiroptera) in the state of Espírito Santo, southeastern Brazil
}

\author{
Rafaela Duda*, Jeronymo Dalapicolla and Leonora Pires Costa
}

\author{
Universidade Federal do Espírito Santo, Departamento de Ciências Biológicas, Laboratório de Mastozoologia e Biogeografia. Avenida Marechal \\ Campos, 1468, Maruípe. CEP 29043-900. Vitória, ES, Brazil. \\ * Corresponding author. E-mail: rafadudac@gmail.com
}

\begin{abstract}
Furipterus horrens has its distribution restricted to the Neotropics. In the coastal states of Southeastern Brazil covered by Atlantic Forest, few records are known and the Espírito Santo state has never been included as an area of occurrence of the species. Here, we report the collection and identification, using morphological and molecular data, of a single individual from Floresta Nacional do Rio Preto, Conceição da Barra, which is the first record in Espírito Santo and fills in a gap in the known geographical distribution of this bat in the Atlantic Forest.
\end{abstract}

The smoky or thumbless bat Furipterus Bonaparte, 1837 is a monotypic genus represented by the species Furipteurs horrens (F. Cuvier, 1828). Along with Amorphochilus schnablii W. Peters, 1877, which occurs in western South America from coastal Ecuador through Peru into northern Chile (Gardner 2008), they are the extant representatives of family Furipteridae. Furipterus horrens has an exclusively Neotropical distribution, occurring in Central America (Panama and Costa Rica), the island of Trinidad, and in South America, in Colombia, Venezuela, south of the Rio Orinoco, the Guianas, eastern Peru, and Brazil, southward into the state of Santa Catarina (Gardner 2008). In Brazil, there are sparse records in the Cerrado, Caatinga and in the Amazonian and Atlantic forests (Paglia et al. 2012), always in association with humid vegetation (Figure 1).

Due to its wide distribution, this species is listed as Least Concern on the IUCN Red List of Threatened Species (Miller et al. 2008). It is seldom recorded in surveys due to sampling difficulties, usually attributed to mist net inefficiency, even when these are placed at the entrance or inside their shelters (Uieda et al. 1980). This low trapping success may explain the scarcity of specimens of this taxon in scientific collections (Bredt et al. 1999). Accordingly, there are only 108 voucher specimens with occurrence in Brazil, according to a search in the online databases speciesLink (http://splink.cria.org.br) and GBIF Data Portal Classification (http://data.gbif.org). Here we report the first record of $F$. horrens in the state of Espírito Santo, southeastern Brazil, filling a significant gap in its known geographical distribution in the coastal Brazilian Atlantic Forest. We also provide a map (Figure 1) of the current known records for the species, including the new record from Espírito Santo, registering 32 points of occurrence, according to a search in the literature (Gardner 2008; Novaes et al. 2012) and in collection databases (speciesLink and GBIF Data Portal). The closest records of the Espírito Santo locality are located $600 \mathrm{~km}$ to the north (Bahia; Gardner 2008), $750 \mathrm{~km}$ to the south
(Praia da Sumaca, RJ; Gardner 2008), and $580 \mathrm{~km}$ to the west (Parque Nacional Cavernas do Peruaçú, MG; Tavares et al. 2010).

The species was registered during a mammal survey at Floresta Nacional (FLONA) do Rio Preto (18²1'19" S, 3950'39” W), municipality of Conceição da Barra, a protected area of Atlantic Forest in northern Espírito Santo (Figure 1). A single adult male was found, during the day, in an abandoned barbecue area by an employee of this protected area on December $10^{\text {th }}, 2009$. The specimen is preserved in $70 \%$ alcohol with the skull removed, and is housed in the mammal collection at Universidade Federal do Espírito Santo, Vitória, Brazil (UFES-MAM 2005).

A tissue sample preserved in alcohol is deposited in the tissue collection at UFES, Vitória, Espírito Santo, Brazil (UFES-CTA 2013). Morphological identification was based on the characters described by Gardner (2008), with additional molecular data. DNA was extracted following the protocol described by Bruford et al. (1992) and used in the polymerase chain reaction (PCR) to amplify 657 base pairs of the Cytochrome-C Oxidase I gene (COI) using primers LCO1490 and HCO2198 (Hebert et al. 2003). The $25 \mu \mathrm{L}$ PCR reaction solution included $2.5 \mu \mathrm{L}$ of $10 \mathrm{x}$ PCR buffer, $1.0 \mu \mathrm{L}$ of $\mathrm{MgCl}_{2}(50 \mathrm{mM}), 0.5 \mu \mathrm{L}$ of dNTP mixture (10 mM of each oligonucleotide), $0.3 \mu \mathrm{L}$ of Platinum Taq DNA polymerase (Invitrogen), $0.3 \mu \mathrm{L}$ of each primer (10 $\mu \mathrm{M})$, and $2 \mu \mathrm{L}$ of DNA template $(100 \mathrm{ng} / \mu \mathrm{L})$. PCR profile consisted of an initial denaturation at $94^{\circ} \mathrm{C}(5 \mathrm{~min})$, followed by 39 cycles comprising denaturation at $94^{\circ} \mathrm{C}$ (30 s), annealing at $44^{\circ} \mathrm{C}(45 \mathrm{~s})$ and extension at $72^{\circ} \mathrm{C}(45$ s), with a final cycle of $72^{\circ} \mathrm{C}$ (5 min). PCR products were purified using the enzyme ExoSAP-IT (USB Corporation, Cleveland, USA). Sequencing was performed by using the Big Dye Terminator Cycle Sequencing kit version 3.1 and an ABI Prism 310 automated sequencer (Applied Biosystems, Foster City, USA), according to the manufacturer's instructions. Sequences were aligned using Clustal W in the program MEGA 5 (Tamura et al. 2011). The same software was used to calculate pairwise sequence divergence, with 
a Kimura two-parameter distance model (K2p; Kimura 1980). The data matrix included the new sequence from Espírito Santo (deposited in Genbank under the accession number JX989224) and six other COI sequences from Genbank: four from Furipterus horrens (EF080358 and JF459160 from Guyana, EU096741-42 from Suriname) and one from each outgroup, Carollia castanea (JF448773 from Ecuador) and Micronycteris brosseti (JF448067 from Guyana).

Furipterus horrens specimen reported in this paper presents all the diagnostic features listed in Gardner

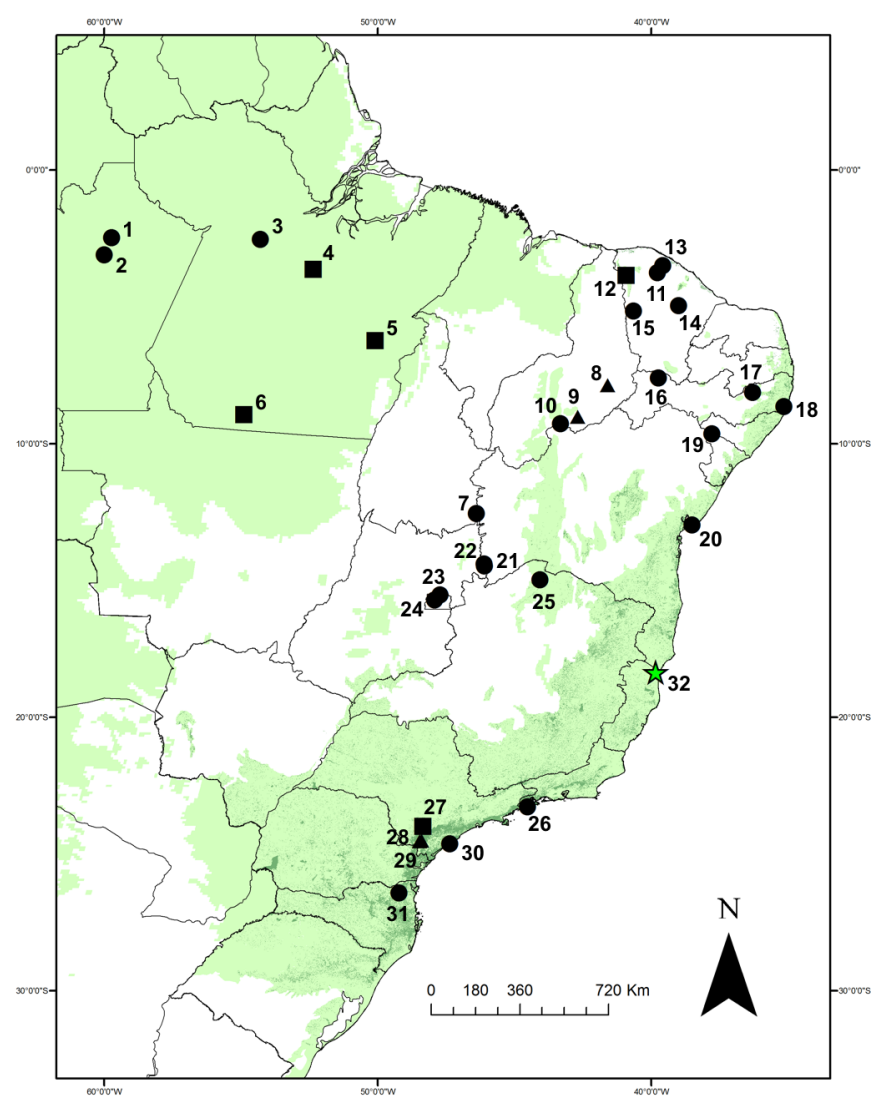

FIgURE 1. Collecting localities of Furipterus horrens in Brazil. The light green shadow illustrates the original forested areas, and the dark green shadow indicates the current remaining fragments of Atlantic Forest. Triangles refer to databases records (speciesLink and GBIF Data Portal), circles to literature records (according to Gardner 2008; Novaes et al. 2012), and squares to both, databases and literature records. Specific localities are listed: 1 . Amazonas, $80 \mathrm{~km}$ north of Manaus $\left(02^{\circ} 30^{\prime} \mathrm{S}\right.$, $59^{\circ} 43^{\prime} \mathrm{W}$ ); 2 . Amazonas, Manaus (0306' S, $\left.60^{\circ} 00^{\prime} \mathrm{W}\right)$; 3. Pará, Taperinha $\left(02^{\circ} 31^{\prime} \mathrm{S}, 5^{\circ} 17^{\prime} \mathrm{W}\right)$; 4. Pará, Cachoreira do Espelho $\left(03^{\circ} 37^{\prime} \mathrm{S}, 52^{\circ} 22^{\prime}\right.$ W); 5. Pará, Floresta Nacional de Carajás (0604' S, 50¹3’ W); 6. Pará, Cachimbo (08 $57^{\prime}$ S, 545ㅇ' W); 7. Tocantins, Aurora do Tocantins, Maciço dos Moura (12³4'53.4” S, 46³0’59” W); 8. Piauí, Arara (0449' S, 4054' W); 9. Piauí, São Raimundo Nonato (0900' S, $42^{\circ} 41^{\prime}$ W); 10 . Piauí, Parque Nacional da Serra das Confusões (09 $13^{\prime}$ S, $43^{\circ} 29^{\prime}$ W); 11. Ceará, Irauçuba (0344' S, 3947' W); 12. Ceará, Gruta de Ubajara (0348' S, 4052' W); 13. Ceará, Itapipoca $\left(03^{\circ} 30^{\prime} \mathrm{S}, 39^{\circ} 35^{\prime} \mathrm{W}\right)$; 14 . Ceará, Quixadá $\left(04^{\circ} 58^{\prime} \mathrm{S}\right.$, $39^{\circ} 01^{\prime}$ W); 15. Ceará, Crateús, Serra das Almas (05¹0’ S, 4040’ W); 16. Pernambuco, Exu (07³0' S, 3942' W); 17. Pernambuco, Brejo Madre de Deus (08 $\left.08^{\prime} \mathrm{S}, 36^{\circ} 22^{\prime} \mathrm{W}\right)$; 18. Pernambuco, Rio Formoso $\left(08^{\circ} 39^{\prime} \mathrm{S}\right.$, $35^{\circ} 09^{\prime}$ W); 19. Sergipe, Canindé de São Francisco (09³8' S, 3747’ W);

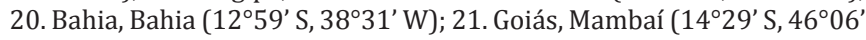

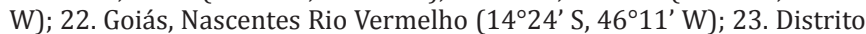
Federal, Planaltina $\left(15^{\circ} 32^{\prime} \mathrm{S}, 47^{\circ} 44^{\prime} \mathrm{W}\right) ; 24$. Distrito Federal, Rural Area $\left(15^{\circ} 44^{\prime}\right.$ S, 47 $57^{\prime}$ W); 25. Minas Gerais, Parque Nacional Cavernas do Peruaçú $\left(15^{\circ} 05^{\prime} \mathrm{S}, 44^{\circ} 15^{\prime} \mathrm{W}\right)$; 26. Rio de Janeiro, Praia da Sumaca $\left(23^{\circ} 17^{\prime}\right.$

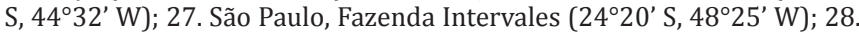
São Paulo, Iporanga (243' S, 48³5’ W); 29. São Paulo, Apiaí, São Paulo (243' S, 48²4' W); 30. São Paulo, Estação Ecológica da Juréia-Itatins

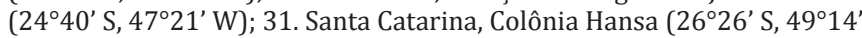
W); 32 . The new record in the state of Espírito Santo, Conceição da Barra, Floresta Nacional do Rio Preto (18²1'19" S, 3950’39” W).
(2008): dorsal fur slate-gray, ventral pelage as in the dorsum, with the tips of the fur slightly paler. The tail is completely wrapped in the uropatagium and extends slightly less than two-thirds of its length. The muzzle is relatively simple and well furred; there are no fleshy structures under the chin; the palate is short, and does not extend well beyond the last molar; the mesopterygoid fossa is longer than wide (Figure 2). Furthermore, the cranial characters of $F$. horrens reported by Husson (1962) are also observed in the collected specimen: the rostrum is short, about half the length of the braincase; upper incisors in pairs, the outer slightly smaller than the inner; the space between the two inner incisors and that between the outer incisor and the canine are distinct; upper canine small, its shaft about equal in height to the large second premolar; first upper premolar about half the size of both the canine and the second premolar; lower incisors with trifid cutting edges, forming a continuous row between the canines; lower canine as high as both the second and the third premolars, which are of about equal size; first lower premolar about half the height of the canine (Figure 2).

The external and cranial measurements (in millimeters) of the specimen, according to Simmons and Voss (1998), were taken with a digital caliper to the nearest $0.01 \mathrm{~mm}$ : total length $=64.4$; tail length $=25.2$; hind foot length= 7.53; ear length= 8.92; tragus length= 2.46; forearm length $=36.95$; greatest length of the skull= 11.49; zygomatic breadth= 6.82; condyloincisive length= 12.03; maxillary toothrow length $=4.08$; breadth across molars $=4.86$. The weight was $1 \mathrm{~g}$ and it was taken with a Pesola scale (precision $=0.5 \mathrm{~g}$ ). These measurements are very similar to those obtained in previous works (Husson 1962, 1978; Simmons and Voss 1998; Pol et al. 2003). Intraspecific divergence between the sample from Espírito Santo and from the Guianas varied from $2.1 \%$ to $2.5 \%$, while interspecific divergence varied from $21.2 \%$ to $25.4 \%$.

Although there have been several bat surveys in the state of Espírito Santo (Luz et al. 2009; Vieira et al. 2010; Peracchi et al. 2011), collecting localities are concentrated in central to southern areas, and until now F. horrens had never been recorded. With this new record, the number of bat species occurring in the state (Mendes et al. 2010; Pimenta et al. 2010; Peracchi et al. 2011) increases to 68. Although the species' natural history is very poorly known, some aspects of its biology are described in the literature. Flight activity begins at twilight, but these bats do not leave the shelters until after dark (Gardner 2008). They are insectivorous animals that fly close to the ground (La Val 1977), especially in search of moths (Fenton et al. 1999). Although this species has been associated with caves, its presence has been recorded in other kinds of refuges, like buildings, tunnels, among boulders, hollow logs and within or under fallen trees in decomposition (Uieda et al. 1980; Simmons and Voss 1998; MacDonald 2006; Fabián 2008; Tavares et al. 2010). Even in caves, they have been observed roosting in holes in the walls (Nowack 1999), which denotes its preference to hide in crevices. Individuals do not touch each other when roosting in groups (Uieda et al. 1980; Bredt et al. 1999).

The northern part of Espírito Santo is among the top 10 priority areas for conservation in the state, both in 
terms of fauna and flora diversity and endemism (Loiola et al. 2011). Considering that the records of $F$. horrens seems to occur in association with humid forests (Handley 1976; Uieda et al. 1980), and that the Atlantic Forest in the Espírito Santo state has suffered high deforestation rates (Lederman and Padovan 2005), reflecting in a high number of threatened mammal species (Chiarello et al. 2007), this new record indicates that specific efforts to investigate new localities of occurrence should be made.

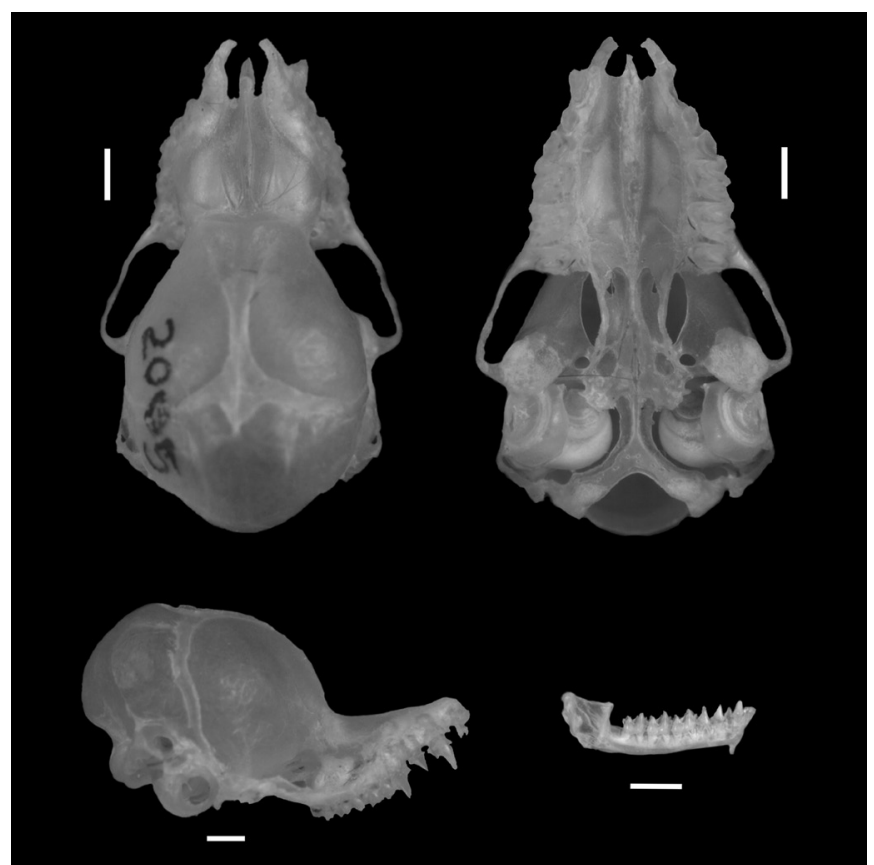

FIGURE 2. Dorsal, ventral and lateral views of the skull, and lateral view of the mandible of the specimen of Furipterus horrens collected at Floresta Nacional do Rio Preto, Conceição da Barra, Espírito Santo (UFES-MAM 2005). Scale bar $=2 \mathrm{~mm}$.

ACKNOWLedgments: We thank Vinícius Pimenta for providing important literature. R. Duda received an undergraduate scholarship from Fundo de Amparo à Ciência e Tecnologia do Espírito Santo (FAPES). J. Dalapicolla received an undergraduate scholarship from Universidade Federal do Espírito Santo (UFES). This work was supported by a grant from Conselho Nacional de Desenvolvimento Científico e Tecnológico (CNPq) to L. P. Costa. The specimen was collected under permit number 203791 from Instituto Brasileiro do Meio Ambiente e dos Recursos Naturais Renováveis (IBAMA).

\section{LITERATURE CiTED}

Bredt, A., W. Uieda and E.D. Magalhães. 1999. Morcegos cavernícolas da região do Distrito Federal, centro-oeste do Brasil (Mammalia, Chiroptera). Revista Brasileira de Zoologia 16(3): 731-770.

Bruford, M.W., O. Hanotte, J.F.Y. Brookfield and T. Burke. 1992. SingleLocus and DNA fingerprinting; p. 225-269 In A.R. Hoelzel (ed.). Molecular genetic analyses of populations: a practical approach. New York: Oxford University Press.

Chiarello, A.G., L.P. Costa, Y.L.R. Leite, M. Passamani, S. Siciliano and M. Zortéa. 2007. Os Mamíferos Ameaçados de Extinção no Estado do Espírito Santo; p. 29-39 In M. Passamani and S.L. Mendes (ed.). Espécies da Fauna Ameaçadas de Extinção no Estado do Espírito Santo. Vitória: Instituto de Pesquisas da Mata Altântica.

Fabián, M.E. 2008. Quirópteros do bioma caatinga, no Ceará, Brasil, depositados no Museu de Ciências Naturais da Fundação Zoobotânica do Rio Grande do Sul. Chiroptera Neotropical 14(1): 354-359.

Fenton, M.B., J.O. Whitaker Jr., M.J. Vonhof, J.M. Waterman, W.A. Pedro, L.M.S. Aguiar, J.E. Baumgarten, S. Bouchard, D.M. Faria, C.V. Portfors, N.I.L. Rautenbach, W. Scully and M. Zortéa. 1999. The diet of bats from southeastern Brazil: The relation to echolocation and foraging behavior. Revista Brasileira de Zoologia 16(4): 1081-1085.

Gardner, A.L. 2008. Family Furipteridae Gray, 1866; p. 389-392 In A.L. Gardner (ed.). Mammals of South America. Volume 1: Marsupials, Xenarthrans, Shrews, and Bats. Chicago: The University of Chicago Press.
Handley, C.O., Jr. 1976. Mammals of the Smithsonian Venezuelan Project. Brigham Young University Science Bulletin, Biological Series 20(5): 1-91.

Hebert, P.D.N., A. Cywinska, S.L. Ball and J.R. Waard. 2003. Biological identifications through DNA barcodes. Proceedings of the Royal Society of London, B. Biological Sciences 270: 313-332.

Husson, A.M. 1962. The bats of Suriname. Zoologische Verhandeligen 58: 1-282.

Husson, A.M. 1978. The mammals of Suriname. Leiden: E.J.Brill. 569 p.

Kimura, M. 1980. A simple method for estimating evolutionary rates of base substitutions through comparative studies of nucleotide sequences. Journal of Molecular Evolution 16: 111-120.

La Val, R.K. 1977. Notes on some Costa Rican bats. Brenesia (Museo Nacional de Costa Rica) 10/11: 77-83.

Lederman, M.R. and M.P. Padovan. 2005. Conservação da Mata Atlântica no Estado do Espírito Santo: Cobertura florestal e Unidades de Conservação. Vitória: Instituto de Pesquisas da Mata Atlântica. 142 p.

Loiola, G.R., D. Lettieri and F.C. Ferreira. 2011. Áreas e ações prioritárias para a conservação da biodiversidade da Mata Atlântica no estado do Espírito Santo. Vitória: Instituto de Pesquisas da Mata Atlântica. 64 p.

Luz, J.L., L. M. Costa, E.C. Lourenço, L.A.C. Gomes and C.E.L. Esbérard. 2009. Bats from the Restinga of Praia das Neves, state of Espírito Santo, Southeastern Brazil. Check List 5(2): 364-369.

MacDonald, D. 2006. The encyclopedia of mammals. London: Brown Reference Group. 976 p.

Mendes, P., T.B. Vieira, M. Oprea, S.R. Lopes, A.D. Ditchfield and M. Zortéa. 2010. O conhecimento sobre morcegos (Chiroptera: Mammalia) do estado do Espírito Santo, sudeste do Brasil. Papéis Avulsos de Zoologia 50(22): 363-373.

Miller, B., F. Reid, J. Arroyo-Cabrales, A.D. Cuarón and P.C. de Grammont. 2008. Furipterus horrens. In IUCN 2011. IUCN Red List of Threatened Species. Version 2011.2. Electronic database accessible at www. iucnredlist.org. Captured on 23 April 2012.

Novaes, R.L.M., R.F. Souza, S. Felix, C. Sauwen, G. Jacob and L.S. Avilla. In press. New record of Furipterus horrens Cuvier, 1828 (Mammalia, Chiroptera) from the Cerrado of Tocantins state with a compilation of the known distribution within Brazil. Check List 8(6): 1359-1361.

Nowak, R. 1999. Walker's Mammals of the World, Volume 1, 6th Edition. Baltimore and London: The Johns Hopkins University Press. 2015 p.

Paglia, A.P., G.A.B. da Fonseca, A.B. Rylands, G. Herrmann, L.M.S. Aguiar, A.G. Chiarello, Y.L.R. Leite, L.P. Costa, S. Siciliano, M.C.M. Kierulff, S.L. Mendes, V.C. Tavares, R.A. Mittermeier and J.L. Patton. 2012. Lista Anotada dos Mamíferos do Brasil / Annotated Checklist of Brazilian Mammals. 2a Edição/2nd Edition. Arlington: Conservation International. 76 p.

Peracchi, A.L., M.R. Nogueira and I.P. Lima. 2011. Novos achegos à lista dos quirópteros do município de Linhares, estado do Espírito Santo, sudeste do Brasil (Mammalia, Chiroptera). Chiroptera Neotropical 17(1): 842-852.

Pimenta V.T., C.T. Machel, B.S. Fonseca and A.D. Ditchfield. 2010. First occurrence of Lonchophylla bokermanni Sazima, Vizotto \& Taddei, 1978 (Phyllostomidae) in Espírito Santo State, Southeastern Brazil. Chiroptera Neotropical 16(2): 740-742.

Pol, A., M.R. Nogueira and A.L. Peracchi. 2003. Primeiro registro da família Furipteridae (Mammalia, Chiroptera) para o Estado do Rio de Janeiro, Brasil. Revista Brasileira de Zoologia 20(3): 561-563.

Simmons, N.B. and R.S. Voss. 1998. The mammals of Paracou, French Guiana: a Neotropical lowland rainforest fauna. Part 1. Bats. Bulletin of the American Museum of Natural History 237: 1-219.

Tamura, K., D. Peterson, N. Peterson, G. Stecher, M. Nei and S. Kumar. 2011. MEGA5: Molecular Evolutionary Genetics Analysis using Maximum Likelihood, Evolutionary Distance, and Maximum Parsimony Methods. Molecular Biology and Evolution 28: 2731-2739.

Tavares, V., C.F.S. Palmuti, R. Gregorin and T.T. Dornas. 2012. Morcegos; p. 156-173 In F.D. Martins, A. Castilho, J. Campos, F.M. Hatano and S.G. Rolim (ed.). Fauna da Floresta Nacional de Carajás: estudos sobre vertebrados terrestres. São Paulo: Nitro Imagens.

Uieda, W., I. Sazima and A. Storti-Filho. 1980. Aspectos da biologia do morcego Furipterus horrens (Mammalia, Chiroptera, Furipteridae). Revista Brasileira de Biologia 40(1): 59-66.

Vieira, T.B., P. Mendes, S.R. Lopes, M. Oprea and A.D. Ditchfield. 2010. Quirópteros (Mammalia, Chiroptera) do município de Alfredo Chaves, Estado do Espírito Santo, Brasil. Revista Brasileira de Zoociências 12(1): 95-102.

RECEIVED: May 2012

ACCEPTED: October 2012

Published ONLINE: December 2012

EDITORIAL RESPONSIBILITY: Valéria da Cunha Tavares 